\title{
A CONSTRUÇÃO DO AGIR DOCENTE POR PROFESSORAS DE LÍNGUA INGLESA PARA CRIANÇAS: UM OLHAR PARA O ENSINO COMO TRABALHO
}

\author{
Giuliana Castro BROSSI* \\ Juliana Reichert Assunção TONELLI**
}

- RESUMO: Este artigo objetiva conhecer a atividade do/a professor/a de língua inglesa para crianças (LIC) e as dimensões desse agir com base nos fundamentos teórico-metodológicos do Interacionismo Sociodiscursivo (ISD) (BRONCKART, 1999-2003, 2007, 2008). Os dados foram retomados de dois estudos de caso desenvolvidos em 2014 e 2016. O aporte teórico adotado discute a lacuna existente na formação de professores/as de LIC (ROCHA; TONELLI; SILVA, 2010; TONELLI; FERREIRO; BELO-CORDEIRO, 2017; SANTOS; BENEDETTI, 2009) no que diz respeito às particularidades da criança (VYGOTSKY, 1998) e à formação de cidadãos críticos (ROCHA; BASSO, 2007; PESSOA; BORELLI, 2011). O ensino como trabalho e a constituição do agir docente (FAĬTA, 2004; AMIGUES, 2004; MACHADO, 2004) ancoram as análises dos discursos das professoras investigadas, e para a geração de dados foram utilizados questionários, entrevistas e uma sessão reflexiva mediada por desenho. A análise dos dados reforçou a relevância da formação de professores/as com foco nas especificidades da atividade do/a professor/a de LIC que é constituída de todas as dimensões do humano. A análise também desvelou crenças das professoras a respeito do ensino de LIC na escola pública, e a influência do imperialismo linguístico.

- PALAVRAS-CHAVE: atividade docente; ergonomia; formação crítica de professores; inglês para crianças; interacionismo sociodiscursivo.

\section{Introdução}

O ensino de língua inglesa para crianças ${ }^{1}$ (doravante LIC) tem sido foco de estudos em contextos diversos, tanto no exterior, quanto no Brasil, em tentativas de compreender

\footnotetext{
* Universidade Estadual de Goiás (UEG). Inhumas - GO - Brazil. giulianabrossi70@gmail.com. ORCID: 0000-00030130-843X

** Universidade Estadual de Londrina (UEL). Centro de Letras e Ciências Humanas (CLCH). Londrina - PR - Brazil. teacherjuliana@uol.com.br. ORCID: 0000-0001-5102-5847

1 Este estudo está vinculado ao Grupo de pesquisa (Capes/-CnpQ) formação de professores e ensino de línguas para crianças FELICE, liderado pela segunda autora e foi desenvolvido no bojo das reflexões entre seus membros. O artigo está também vinculado ao projeto de extensão Teachers of English in Action (TEIA), cadastrado na Pró-reitoria de
} 
e de sistematizar o ensino e a aprendizagem, assim como a formação de professores/as de LIC, considerando a ausência de prescrições e orientações para esse contexto. De acordo com Enever (2011), houve, na primeira década do novo século, aumento na procura pelos pais em fornecer oportunidades às crianças de aprenderem um idioma estrangeiro no contexto europeu. No cenário brasileiro, para se ter uma ideia, a investigação de Tanaca (2017) revelou que dentre 4.739 municípios brasileiros, 2.812 possuem oferta de LIC para o ensino fundamental I (doravante EFI). Estudos demonstram ainda que, no Brasil, nos últimos anos, o ensino de LIC tem sido implantado em contextos de ensino privado (TONELLI, 2005; LEMES, 2017; SELBACH; SARMENTO, 2017) e público (COLOMBO; CONSOLO, 2017; DIAS; BROSSI, 2015; MELLO, M., 2017; ANDRADE; CONCEIÇÃO, 2017; BUOSE; SANTOS, 2017; DIAS, 2014; MONTEIRO, 2016; SANTOS, 2005, 2009), foco desta investigação.

Apesar da sua não obrigatoriedade nos anos iniciais do EFI, no Brasil, a LIC no EFI público é uma realidade, em forma de projetos e/ou como disciplina da grade curricular. Independente do contexto e de sua organização, o fato é que os/as professores/ as que se enveredam por esses caminhos enfrentam desafios, tais como o despreparo para lidar com esse público específico, a falta de políticas públicas e as diretrizes orientadoras do ensino, a carência de cursos de formação docente, a falta de material didático, dentre outros.

Estudos na área da linguística aplicada (CELANI, 2016; MOITA LOPES, 2006; TONELLI; CRISTOVÃO, 2010; SANTOS, 2009, dentre outros) defendem a garantia de condições para que todos os indivíduos, incluindo as crianças, possam aprender línguas estrangeiras (LE). Apesar da ausência de políticas que assegurem o ensino de LE para crianças dos anos iniciais (CHAGURI; TONELLI, 2012) e também a formação adequada para o/a profissional dessa esfera nos cursos de letras, diversos estudos apresentam iniciativas de ensino de LE nas escolas do EFI no Brasil (COLOMBO; CONSOLO, 2017; DIAS; BROSSI, 2015; MELLO, M., 2017; ANDRADE; CONCEIÇÃO, 2017; TONELLI; FERREIRO; BELO-CORDEIRO, 2017).

No contexto investigado, o ensino de LIC foi regulamentado em 2006, sem que houvesse qualquer formação para os/as profissionais, que já atuavam no ensino de língua inglesa (doravante LI) nos anos finais. Isto é, o perfil das crianças, os objetivos a serem alcançados e a prática social oportunizada por meio do uso da LI na vida desses aprendizes de seis a 12 anos não foram fatores especificamente tratados em momentos de formação inicial ou continuada. A esse respeito, Pessoa e Borelli (2011), ao problematizar sobre o ensino de LE, reforçam que é primordial que nós, professores/ as de línguas estrangeiras, reconheçamos o nosso papel de agentes transformadores, apesar de tantas intervenções advindas das instituições, da sociedade das políticas linguísticas (ou falta delas). As autoras reiteram que

Extensão da UEL sob número 02372, e ao projeto de extensão English for Kids: inglês, comunidade e empoderamento social, da UEG, Inhumas, cadastrado na Pró-reitoria de Extensão, sob o código 9820. 
Dentro desse contexto estão nossas ações, cabendo a nós, então, questionar os interesses que têm orientado nossa prática, a relevância do que ensinamos aos[às] nossos[as] alunos[as] e a maneira como temos desempenhado nosso papel social. (PESSOA; BORELLI, 2011, p.25).

Enfatizamos o fato de que nossas ações como professores/as de LI para crianças podem propiciar práticas sociais que empoderem as crianças a expressarem-se com criatividade e agência na sociedade onde vivem. Pautadas nessa ideia, para este estudo, apropriamo-nos das ideias de pesquisadores que se ocupam e defendem a formação de professores/as de LI e as recontextualizamos para o contexto de LIC. Sobre a formação crítica de professores, Pessoa e Borelli (2011, p.12) afirmam que

[...] busca enfrentar o conflito social sobre a finalidade do ensino e as consequências da aprendizagem em sala de aula. Objetiva, em suma, desenvolver uma prática reflexiva crítica e criativa, não simplesmente reprodutora. Tal prática inspira os estudos [...], que concebem professores em formação universitária e continuada como atores cuja formação docente é fundamental por saberes que eles mobilizam e por significados que eles mesmos produzem. Esses saberes que orientam essa ação precisam ser desenvolvidos e valorizados para que possam promover mudanças mais significativas no processo educacional, gerando resultados positivos na aprendizagem de todos os alunos $[\ldots]$

Em consonância com as autoras, partimos da premissa de que os/as professores/as de LIC precisam desenvolver uma "prática reflexiva crítica e criativa, não simplesmente reprodutora" (PESSOA; BORELLI, 2011, p.12) e, defendemos um currículo de formação inicial para o ensino de LI que contemple a inserção de disciplinas, estágio, iniciação científica e ações de extensão que favoreçam o desenvolvimento de capacidades e competências para lidar com as especificidades da atividade docente de LIC.

A esse respeito, Rocha e Basso (2007, p.16) asseveram que

[...] isso significa pensar quem é o aluno do Fundamental I, como ele possivelmente está discursivamente constituído, por que e para que ele precisa aprender o inglês, entre outras línguas. É igualmente importante ponderar qual a maneira mais efetiva de fazê-lo, garantindo-se, em sala de aula, o trabalho com a pluralidade linguística e cultural, a reflexão sobre as práticas opressoras e a materialização de princípios que permitam ao aluno aprender essa língua para seu fortalecimento como cidadão do mundo.

Nesse sentido, analisar o trabalho dos/as professores/as de LIC, nos dizeres de quem atua no referido contexto, alia-se a um entendimento mais amplo do que o conhecimento 
das ferramentas pedagógicas utilizadas por eles/as, ou a abordagem que orienta suas práxis $^{2}$. Assim, ensejamos compreender o processo de formação e de desenvolvimento do agir dos/as professores/as de inglês para crianças.

O objetivo geral deste artigo é conhecer a atividade do/a professor/a e as dimensões do seu agir docente com base nos fundamentos teórico-metodológicos do Interacionismo Sociodiscursivo (ISD), tendo como pressuposto que as professoras de LIC participantes desta pesquisa receberam formação inicial para atuar como professoras de inglês para os anos finais do ensino fundamental II (doravante EFII) e para o ensino médio (EM), seguindo os documentos que orientam a formação de professores de inglês em nosso país ${ }^{3}$.

Desta feita, interessadas na análise do agir docente, propomos uma reflexão a respeito da construção das práxis das professoras, semiotizadas em seus discursos. A reflexão a que nos propomos busca responder às seguintes questões: a) O que dizem as professoras investigadas sobre sua formação inicial? e b) De que forma a análise das semiotizações das duas professoras podem contribuir para a formação de professores de LIC?

A organização deste artigo se deu de forma subversiva em relação ao gênero artigo científico, por dois motivos. Primeiro, optamos por iniciar as reflexões partindo do que Stephany, professora de inglês nos anos iniciais do EFI, diz sobre o trabalho docente, antes da fundamentação teórica. Dessa forma, marcamos, propositalmente, a relevância desse discurso ignorado, ou na melhor das hipóteses, preterido à dos/as 'especialistas' teóricos, que muitas vezes não conhecem o contexto em questão; além das teorias e estudos dentro das fronteiras da universidade. Segundo, vemos como premente destacar a reflexão sobre a ação presente nos dizeres de Stephany, uma vez que se fez ouvir no que tange o seu próprio trabalho e agir profissional de LIC, que é uma atividade constituída de gestos complexos, pouco valorizada, e que começa a ser discutida na academia. Acreditamos que este estudo pode contribuir para com a formação continuada de professores/as de LIC, uma vez que estes/as se constituem em seu agir, em uma relação entre os conhecimentos e o agir docente de LI, e a experiência que os/as mesmos/ as vivenciam nesse cenário já existente de LIC nas escolas públicas (TONELLI, 2017). As contribuições se estendem a alunos/as de graduação do curso de letras, professores/ as que já atuam em salas de aula e gostariam de realizar sua atividade de trabalho com o público infantil. Além disso, as reflexões e os questionamentos investigados neste estudo corroboram o arcabouço teórico da área de formação de professores de LIC.

Este artigo está organizado em cinco partes. Na primeira, problematizamos o ensino de LIC como trabalho partindo das teorizações presentes nos dizeres de uma das participantes. Na segunda parte, discutimos acerca da (não) formação dos/as professores/ as de LIC no contexto investigado, além de relacionar a estudos concernentes ao agir

Compreendemos práxis no sentido de Johnson (2006, p.240) que rejeita o debate entre teoria e prática, optando pelo uso do termo práxis que "captura como teoria e prática se estendem um ao outro e como esse processo transformador estende-se ao trabalho do professor". (Tradução nossa).

3 Diretrizes Curriculares para os Cursos de Letras (BRASIL, 2001). 
docente e sua constituição. Para isso, recuperamos pesquisas que contemplam essa temática, apoiadas nos fundamentos teórico-metodológicos do ISD (BRONCKART, 1999-2003), nas ciências do trabalho da ergonomia da atividade (AMIGUES, 2004; MACHADO, 2004; SAUJAT, 2004) e da psicologia do trabalho (FAǏTA, 2004; CLOT, 2007). Em seguida, contextualizamos o estudo metodologicamente. Posteriormente, na análise dos dados, estabelecemos diálogos entre as professoras e os autores/as que fundamentam o estudo, e ao final teceremos nossas considerações finais.

\section{Ouvindo as vozes das professoras de língua inglesa para crianças}

Iniciamos, como anunciado, nossas reflexões com os dizeres de Stephany ${ }^{4}$, professora de LIC na escola A, em 2014, os quais foram conhecidos na entrevista ${ }^{5}$ que compõem o corpus de dados analisados por Dias $(2014)^{6}$.

\section{Excerto 1:}

Stephany $-\{\ldots\}$ Horas que poderiam ser melhor aproveitadas com outros assuntos, inclusive pra trabalhar temas críticos. Melhor aproveitadas, sabe? [...]

$\mathbf{P}^{7}$ - Você tocou no ponto do ensino crítico. Com os anos iniciais, você acha que tem condição de problematizar algum tema, alguma coisa...

Stephany - Nossa, tem que ser com muito cuidado. Nossa! Muito cuidado. Porque são crianças né? São crianças, e eles trazem um monte de visões e preconceitos pra dentro da escola. Então se você não tiver cuidado, nossa, e você der uma aula assim como se você tivesse falando com quem tem maturidade, no outro dia as mães estão todas lá. Isso nunca me aconteceu, mas aconteceria se eu não soubesse o que eu estou fazendo. Aí, por exemplo, eu trabalho família, 'mother, father, brother, sister' no primeiro ano, né? A família nuclear. Só que depois que eu mostro aquela família nuclear, eu falo com eles que existem outros tipos de família também. Existem famílias só de mães, só de pais, de mãe solteira, de pai solteiro... Então existem famílias de todos os jeitos, de homem com homem, de mulher com mulher. E quando eu começo a falar disto, eu já começo a ver a reação deles. Eles se assustam, eles se recusam a ouvir aquilo. Crianças. Então por isso tem que ter cuidado. Então eu não toco muito nessa tecla, mas eu falo que estas famílias existem. [...]Foi o ano passado. As [profissões] que tinham mais prestígio. É, eu acho que era isso. As mais valorizadas na sociedade. Aí eu falei: "Por que a do enfermeiro tá aqui nas desprivilegiadas, das desprestigiadas?". "Uai,

\footnotetext{
Stephany e Iza são os pseudônimos usados para preservar as identidades das professoras, por questões éticas.

No Apêndice A disponibilizamos o roteiro da entrevista realizada com a professora Stephany, em 2013.

Relatado e publicado em Dias e Brossi (2015).

Pesquisadora.
} 
não sei teacher". [...] Então sabe, eu vou dando algumas injeçõezinhas. Só que eles não admitem: "Claro que não teacher". "Será que vocês não estão com preconceito?" [rindo]. Sabe, mas tem que ser aos pouquinhos.

P - Mas eu acho que já faz toda a diferença, né?

Stephany - É... [...] Outra coisa, nesse dia também, eu percebi que tinham muitas mulheres nas desprestigiadas e homens nas melhores profissões, nas concepções deles né? Eu falei: "Por que aqui tem a maioria mulher, desse lado à maioria é mulher e negro e desse lado à maioria é homem?”. Só que eles não conseguem, eles não admitem que têm preconceito. [...] É, mas... no final eu concluí assim: que não é a profissão que eles estavam julgando, sabe? A aparência das pessoas nas fotos, entende? É muito difícil. Muitas vezes eu falava e eles não entendiam, mas eu acho que é questão de maturidade mesmo, mas eu dei o primeiro passo.

(STEPHANY - Entrevista concedida em junho/2014)

Compartilhamos da opinião de Stephany, de que ela deu o primeiro passo. Quantos de nós, professores/as formadores/as, pesquisadores/as e professores/as de LIC teriam a capacidade de aproveitar essa brecha (DUBOC, 2012) em uma ação de ensino crítico no momento da aula, da forma que a professora investigada evidenciou? No momento em que planejava essa atividade, a professora certamente criou hipóteses, ou pelo menos intuiu que questões de gênero e raça apareceriam enviesadas nas discussões entre as crianças do quinto ano. Essa antecipação, porém, provavelmente ocorre caso o/a professor/a tenha sido contemplado(a) com uma formação crítica e transdisciplinar, que favoreça as des(re)construções de conceitos e valores naturalizados no discurso social. Assim, no momento em que os resultados das atividades das crianças se evidenciaram a professora sentiu-se apta a problematizar, mesmo que brevemente, os (pre)conceitos naturalizados que resultaram das imagens analisadas.

Egido (2018) apresenta resultados de seu estudo que evidenciam que aspectos como gênero e etnia formam as percepções e experiências de alunos em salas de aulas de línguas estrangeiras/adicionais, corroborando o entendimento de Stephany, ao relatar as impressões das crianças nas aulas de LIC. Por meio da análise dos dêiticos de pessoa (eu) pode-se afirmar que Stephany se implica em seu discurso, reconhecendo que é uma professora experiente no trecho "se eu não soubesse o que estou fazendo", e demonstra que considera o ensino de inglês para crianças além da educação linguística pura e simplesmente. O excerto inicia-se com a sugestão de Stephany em aproveitar melhor o tempo na escola para problematizar conceitos hegemônicos naturalizados, valorizando o caráter social (JORGE, 2009) do ensino de LIC.

Apesar de a problematização não ser o objeto de discussão deste artigo, é com esse posicionamento crítico-reflexivo da professora que objetivamos discutir a importância da formação crítica de professores/as de LIC. Nossas análises não têm a pretensão de trazer respostas ou receitas bem-sucedidas, no entanto pautamo-nos no constante 
questionamento, e instigamos os/as leitores/as a, pelo menos, pensar nas questões que propomos. Nós, formadores/as de professores/as, mediamos e incentivamos a reflexão na ação de nossos/as professores/as de LIC? O/a professor/a graduado/a em letras está preparado para o trabalho de ensinar inglês para crianças? Como se configura o trabalho do/a professor/a de LIC? Há gestos e traços característicos de professoras/es de LIC?

\section{Quem são as professoras ${ }^{8}$ de língua inglesa para crianças?}

Iniciamos este artigo trazendo a fala de Stephany para, a partir dela e do cenário educacional já existente, investigar a forma como este já se configura, e não somente formular um perfil ideal de professores/as de LIC. Pretendemos também conhecer o que as professoras de LIC relatam acerca do trabalho de ensinar, na intenção de compreender a constituição do agir dessas professoras e, partindo disso, construir teorizações, sem a intenção de prescrever um 'perfil do/a professor/a bem-sucedido/a', mas com o objetivo de assinalar traços e gestos do agir docente de LIC.

Nesse sentido, destacamos que as/os profissionais que atuam com o ensino de LIC constroem seu agir docente à medida que se inserem no campo de atuação. Essas/es educadores/as que atuam no EFI no município em questão, em Goiás, são egressas do curso de letras e, portanto, formadas para atuar no contexto de EFII e EM. Na experiência de estágio supervisionado de inglês, o primeiro contato com o coletivo de professores/as de educação básica ocorre em salas de aula de inglês desde o sexto ano. Os documentos oficiais estudados na graduação como, por exemplo, a Lei de Diretrizes e Bases da Educação (LDB), os Parâmetros Curriculares Nacionais (PCN), a Base Nacional Comum Curricular (BNCC) com início em 2020 - norteiam as escolhas, o planejamento e o agir docente - são especificamente voltados para alunos/as do EFII. Assim, o término do curso de letras português/inglês marca o início da formação continuada - realizada na prática docente e sem diretrizes específicas - para os/as professores/as de inglês que optarem por lecionar nos anos iniciais do EFI (TUTIDA, 2016; DIAS; BROSSI, 2015)

Em sua dissertação, Tutida problematiza a (não) formação de professores/as de LIC a contar da própria experiência em lecionar inglês nos anos iniciais, e sua busca por compreender e construir os saberes necessários ao profissional que atua no ensino de inglês para crianças do EFI, logo após o término da sua formação inicial. A esse respeito, Santos (2009, p.176) elenca características desejáveis aos/às professores/as de LIC.

Ser graduado na LE a ser ensinada; gostar da área de ensino de LE; conhecer o conteúdo dessa área e adequá-lo à faixa etária; Usar metodologias atrativas e dinâmicas; Conhecer teorias sobre o desenvolvi-

\footnotetext{
Adotamos a flexão professor/as para nos referir ao conjunto de profissionais que atuam no setor. A partir de agora, optamos pelo feminino para nos referir às duas professoras participantes do estudo.
} 
mento da criança; Aperfeiçoar-se constantemente por meio de cursos e outro eventos; Mostrar-se aberto à aprendizagem; Conhecer teorias de ensino-aprendizagem de línguas; Ter nível adequado de proficiência na língua-alvo para atuar com crianças.

Concordamos com a autora e enfatizamos a relevância de oportunizar aos/ às professores/as de LI, em formação inicial, momentos de observação e regência docente, incluindo em LIC, para proporcionar a vivência e as reflexões no tocante às especificidades do trabalho docente com crianças dos anos iniciais. A complexidade envolvida no processo de formação de professores/as de LI é notória, e as limitações impostas pelo currículo do curso de letras português/inglês e respectivas literaturas, e o caráter não integral do curso, dificultam a inserção de novos componentes curriculares ou disciplinas no rol de opções do/a estudante de letras. Acreditamos, assim como Santos e Benedetti (2009), que ações de formação continuada podem propiciar aos/ às professores/as de LIC oportunidades de reflexões e ressignificações sobre a práxis docente e sobre o trabalho do/a professor/a de inglês para crianças, com desenvolvimento de gestos e ferramentas mediadoras específicas da atividade de professores/as de LIC. Por isso, defendemos que

O profissional desejável para atuar nesse contexto vai sendo construído levando-se em consideração a perspectiva de inconclusão defendida por Porto (2004), conforme já citada-mediante algumas ações de formação, a partir de um repensar do currículo vigente e da implementação de disciplinas nos Cursos de Letras que contemplem as especificidades requeridas ao docente para atuação com crianças e formação continuada, intencional e planejada, que vise à socialização de experiências. Neste sentido, mediante estudos e ações individuais e coletivas, o professor deve ser concebido como agente de mudanças que sabe fazer uso da língua e ensiná-la com fins comunicativos. (SANTOS; BENEDETTI, 2009, p.348).

Nesse sentido, consideramos necessário compreender o ensino como trabalho e o agir dos/as professores/as de LIC. Com isso, buscamos indícios da emergência de traços e de gestos específicos para o trabalho de ensinar inglês para crianças dos anos iniciais do EFI em escolas públicas de uma cidade localizada na região metropolitana de Goiânia, em turmas de aproximadamente 25-30 crianças.

Tonelli (2016, p.34), por sua vez, reforça a necessidade e a importância do período de observação dos contextos de estágio durante a formação inicial do/a professor/a de LIC. A autora afirma que "a observação prévia dos contextos foi essencial para a tomada de decisões mais conscientes por parte dos alunos-mestres". Além disso, em consonância com Lousada e Machado (2010), defendemos que os/as professores/as constroem e utilizam instrumentos para alcançar seus objetivos. Esses instrumentos 
modificam o ambiente físico ou social, na medida em que ocorrem as interações com os/as professores/as, mas essas do mesmo modo sofrem profundas transformações psíquicas, aumentando seu conhecimento, assim como desenvolvendo capacidades para agir sobre o mundo e sobre o outro. Desse modo, apontamos igualmente que os artefatos precisam combinar-se a outros mediadores, para serem internalizados e se tornarem instrumentos apropriados pelos/as professores/as "disponibilizados pelo meio social" (LOUSADA; MACHADO, 2010, p.629).

Rosolem (2015, p.23) afirma que "os artefatos são objetos, materiais ou simbólicos, que foram construídos pela humanidade para mediarem as ações do homem sobre o ambiente e sobre o outro para atingir sua meta". Concordamos com a autora que, ancorada em Rabardel (1995), aponta que o artefato é apropriado de acordo com as necessidades dos/as professores/as quando passa a ser um instrumento psicológico. $\mathrm{Na}$ concepção vigotskiana, permite-se o desenvolvimento de capacidades. Em outras palavras, para que as funções psicológicas superiores ocorram, o aprendizado é um aspecto essencial (FACCI, 2004). Compartilhamos da opinião de Rosolem (2015, p.26) no sentido de que "ao interagir socialmente, os indivíduos influenciam e são influenciados, passam a comportar-se sob a influência social de um coletivo; a ação individual é impulsionada pela atividade coletiva". Rosolem (2015, p.27) afirma também que as concepções de Vygotsky (1998) formam a base para investigar o agir através da linguagem, levando-nos a identificar os/as professores/as de inglês para crianças investigadas neste estudo, "como seres sócio-históricos e culturalmente situados, cuja intervenção de instrumentos simbólicos pode propiciar o seu desenvolvimento".

De acordo com FAĬTA (2004, p.73), "coerções sistemáticas das situações de trabalho", as quais trazemos para esse contexto no qual nos inserimos, dos/as professores/ as investigados/as, estabelecem atitudes que caracterizam o trabalho docente específico de professores/as de LIC. O autor afirma ainda que há práticas que são forjadas graças aos "elementos constitutivos" (ESPINASSY, 2003), ou "determinações econômicas, técnicas, regimentais obrigam o sujeito a se redefinir a partir de seus próprios valores" (CANGUILHEM, 1975 apud FAĬTA, 2004, p73).

As teorizações acerca das escolhas que "dão sentido à sua atividade", remete-nos a Faĭta (2004, p.77), uma vez que "para dar obrigatoriamente forma a seu modo de ensinar" os/as professores/as refletem e escolhem se vão recorrer àquela norma já estabelecida de ação dentro de determinada situação, ou se decidem "fazê-lo evoluir em função das necessidades". Dito de outro modo, diante de uma situação em aula parecida com a descrita no excerto 1, o/a professor/a de inglês, no terceiro ou quinto ano do EFI, por exemplo, pode optar entre reconhecer a necessidade de problematização de conceitos naturalizados por um discurso hegemônico ao qual somos expostos/as todos os dias, ou continuar reforçando os estereótipos excludentes sentindo-se inapto/a para problematizá-los, mesmo que superficialmente. O que o discurso das/os professores/ as nos revela? Seja qual for a escolha do/a professor/a em questão, a linguagem é o instrumento de trabalho que ele/ela utiliza para agir. Nesse sentido, buscamos apoio teórico-metodológico no ISD para analisar o trabalho dos/as professores/as de LIC, 
ancorados nos estudos das ciências do trabalho da ergonomia da atividade (AMIGUES, 2004; SAUJAT, 2004) e da psicologia do trabalho (FAĬTA, 2004; CLOT, 2007), com o intuito de compreender melhor a constituição da atividade desse/a professor/a.

Para Bakhtin/Volochinov, "todo sistema de normas sociais [...] só existe em relação à consciência subjetiva dos indivíduos que pertencem à coletividade regida por essas normas.” (BAKHTIN-VOLOCHINOV, 1997, p.97).

De acordo com Faŭta (2004, p.66),

O fato de se dar a essas formas de fazer compartilhado um aspecto específico, correspondente a preocupações particulares no quadro de uma atividade comum ao conjunto de uma categoria sócio profissional, permite, sem dúvida alguma, falar de gênero, de um modo homólogo ao que Bakhtin define como gêneros de discurso ou gêneros de linguagem.

Recorremos às considerações de Bakhtin/Volochinov (1997) e Faŭta (2004) no intuito de evidenciar que a ausência de diretrizes sobre a formação do agir do/a professor/a de línguas estrangeiras para crianças no Brasil dificulta sobremaneira o estabelecimento de objetivos que orientem a prática do/a professor/a de LIC. Ainda que não existam formalmente, pertencem à coletividade regida por normas, não materializadas nos documentos oficiais do MEC, de Conselhos Estaduais de Educação, de Projetos Políticos-Pedagógicos de cursos de letras ou de políticas linguísticas e de formação de professores/as de LIC.

No entanto, como se constitui esse/a professor/a de LIC? Emprestamos a descrição de Machado (2007) sobre o trabalho docente no sentido de iniciar as reflexões a respeito da formação dos/as professores/as de LIC e o trabalho de ensinar inglês para crianças,

O trabalho docente, resumidamente, consiste em uma mobilização, pelo professor, de seu ser integral, em diferentes situações - de planejamento, de aula, de avaliação -, com o objetivo de criar um meio que possibilite aos alunos a aprendizagem de um conjunto de conteúdos de sua disciplina e o desenvolvimento de capacidades específicas relacionadas a esses conteúdos, orientando-se por um projeto de ensino que lhe é prescrito por diferentes instâncias superiores e com a utilização de instrumentos obtidos do meio social e na interação com diferentes outros que, de forma direta ou indireta, estão envolvidos na situação. (MACHADO, 2007, p.93).

Pela descrição do agir docente, destacamos o fato de que a prescrição ao trabalho do/a professor/a provém de instâncias superiores à de sua atuação, uma vez que, nós, docentes, pautamos nosso trabalho em diretrizes ou em leis que organizam as diversas esferas da educação linguística. Entretanto, no que diz respeito ao trabalho de ensinar LIC, por não ser reconhecido formalmente nas Diretrizes da Educação Básica, nas 
Diretrizes Curriculares Nacionais (DCN) para a formação inicial de professores/as (BRASIL, 2014) e na atual e recém-aprovada $\left(\mathrm{BNCC}^{9}\right)$, os/as professores/as iniciam sua atividade "diante de restrições provenientes das instituições/empresas, que dão uma configuração inicial à sua ação, frequentemente explicitadas em textos instrucionais ou procedimentais" (MACHADO, 2009, p.80) pautadas na ocupação sugerida sem configuração prescritiva específica.

No que diz respeito ao trabalho dos/as professores/as, buscamos amparo em Bronckart (1999-2003), para quem o trabalho prescrito é desenhado da forma que ele é pré-definido em documentos produzidos pelas empresas ou pelas instituições, que instruem, fornecem modelos, programas etc. Portanto, o "trabalho prescrito" é uma representação do que deve ser o ofício, que é anterior à sua realização efetiva. Essa definição anterior aos afazeres - a prescrição - é uma das dimensões que parece carecer de reformulações no âmbito educacional. Conforme dito anteriormente, não existe no Brasil um documento que se destine exclusivamente a "prescrever" o exercício docente dos/as professores/as de LIC.

Amigues (2004, p.41) afirma que a atividade do/a professor/a é dirigida "aos alunos, à instituição que o emprega, aos pais, a outros profissionais", além de ser "socialmente situada e constantemente mediada por objetos que constituem um sistema" (AMIGUES, 2004, p.42). Concordamos com o autor que elenca alguns objetos constitutivos da atividade dos/as professores/as, os/as quais estabelecem e coordenam as relações que se materializam no agir docente: as prescrições, os coletivos, as regras do ofício e as ferramentas. O trabalho dos/as professores/as de LIC caracteriza-se por prescrições vagas, pouca ou nenhuma orientação metodológica durante a licenciatura em letras, que levam os/as professores/as de LIC a "redefinir para si mesmos as tarefas que lhes são prescritas, de modo a definir as tarefas que eles vão, por sua vez, prescrever aos alunos". (AMIGUES, 2004, p.42). Alicerçados(as) nas prescrições iniciais, os/as professores/as, de maneira coletiva, se autoprescrevem tarefas que são características das dimensões coletivas da atividade docente. No que tange às regras do ofício, elas são aquelas que conectam os/as professores/as de LIC entre si, com uma memória de agir comum a todas e uma "caixa de ferramentas" que são concebidas pelos/as professores/as ou outros, e que podem ser transformadas para se tornarem mais eficazes (AMIGUES, 2004).

A seguir, descrevemos o aparato metodológico que utilizamos nesta investigação, com atenção especial ao contexto das professoras investigadas, assim como na sua constituição sócio-histórica.

\footnotetext{
Apesar da análise do referido documento não fazer parte dos objetivos desta publicação, registramos nosso conhecimento e consciência da lacuna que permanece no que tange ao ensino de LIC. A Base Nacional Comum Curricular (BNCC) 2018 foi aprovada e é atualmente o documento oficial que orienta a Educação no Brasil, desde a educação infantil ao ensino médio. No entanto, o ensino de língua inglesa nos anos iniciais do ensino fundamental I não está previsto no documento, o que infelizmente mantém o trabalho do/a professor/a que atua nessa esfera na informalidade, sem orientações e diretrizes para o/a professor/a.
} 


\section{Contextualizando o estudo}

Esta investigação configura-se como um estudo de caso (YIN, 2001), inserida no paradigma interpretativo. O corpus de dados analisado advém de duas pesquisas desenvolvidas a priori e apresentadas como monografia de conclusão do curso de letras. Dias (2014) e Monteiro (2016) investigaram duas professoras em dois contextos de ensino de LIC (6-13 anos) em uma cidade de pequeno porte do interior de Goiás, onde a LI tem sido ensinada, como parte da matriz curricular do EFI desde 2006.

Os dados analisados neste artigo foram gerados por meio de questionários, entrevistas e sessões reflexivas as quais utilizaram desenhos produzidos pelos participantes como ponto de partida ${ }^{10}$. A entrevista foi desenvolvida por Dias e Brossi (2015) e foi um dos instrumentos para a geração dos dados para o trabalho de conclusão de curso de Dias em 2014. Os questionários e as sessões reflexivas mediadas por desenho foram realizados no curso de extensão que Iza participou em 2014 e 2015 na UEG, UnU Inhumas. As sessões reflexivas mediadas por desenho foram uma das atividades de socialização após a leitura de textos relacionados ao ensino e à formação de professores de línguas estrangeiras para crianças. Brossi, Tonelli e Furio (2018) analisam os dizeres dos participantes do curso de extensão ao falarem sobre o desenho que representava a seguinte indagação: "como você se imagina, se vê como professor de inglês para crianças, em uma sala de aula?". As autoras consideram que as representações acerca do trabalho do professor de inglês para crianças revelam grandes desafios em relação ao ensino como trabalho, ou seja, o agir docente. Os excertos advindos das sessões reflexivas analisados neste artigo são recortes de uma das participantes no curso de extensão, que é professora de LIC na rede municipal de Inhumas/ Go.

O critério de análise dos dados adotado neste estudo é a reflexão fundamentada nos pressupostos sobre o agir docente e sobre a formação crítica de professores/as de LIC. Apresentamos, a seguir, o Quadro 1 que contém informações sobre os perfis das duas professoras investigadas e sobre a geração dos dados nos respectivos estudos (DIAS; BROSSI, 2015) e (MONTEIRO, 2016).

10 A sessão reflexiva mediada por desenho foi uma atividade desenvolvida no curso de extensão do qual Iza participou na UEG. Para maiores detalhes sobre esse instrumento de geração vide Tonelli, Brossi e Furio (2018). 
Quadro 1 - Perfil das professoras investigadas

\begin{tabular}{|c|c|l|l|}
\hline $\begin{array}{c}\text { Professora } \\
\text { 26 anos }\end{array}$ & Escola onde atua & \multicolumn{1}{|c|}{ Formação } & \multicolumn{1}{c|}{ Geração dos dados } \\
\hline Escola A & $\begin{array}{l}\text { Graduada em letras portu- } \\
\text { guês-inglês (UEG), Mestre } \\
\text { em letras e linguística (UFG) } \\
\text { e doutoranda (UFG) }\end{array}$ & $\begin{array}{l}\text { Pesquisa desenvolvida em } \\
\text { 2013. Dados gerados por } \\
\text { meio de observação e notas } \\
\text { de campo de 14 aulas de 50 } \\
\text { minutos, questionários, nar- } \\
\text { rativas e entrevista. } \\
\text { Monografia apresentada em } \\
2014 .\end{array}$ \\
\hline Iza anos & Escolas A e B & $\begin{array}{l}\text { Graduada em letras portu- } \\
\text { guês-inglês (UEG); especia- } \\
\text { lização em docência univer- } \\
\text { sitária (Fabec) }\end{array}$ & $\begin{array}{l}\text { Pesquisa desenvolvida em } \\
2016 \text { Dados gerados por } \\
\text { meio de observação e notas } \\
\text { de campo de 16 aulas obser- } \\
\text { vadas, sendo 12 na escola A } \\
\text { e 4 na escola B, questionário } \\
\text { e sessão reflexiva mediada } \\
\text { por desenho. }\end{array}$ \\
\hline
\end{tabular}

Fonte: Elaboração própria.

A pesquisa de Dias (2014) foi realizada na escola municipal A, onde Stephany era professora de inglês para as turmas de primeiro a quinto anos do EFI. Em 2016, Monteiro (2016) investigou Iza, professora de inglês da escola A, assim como na escola B. Os contextos são caracterizados por Monteiro (2016) como "diferentes" pela localização privilegiada da escola A. Todavia, ambas as escolas possuem salas de aula pequenas, com pouco espaço de mobilidade para atividades lúdicas e de expressão corporal. Até mesmo a mudança na disposição das carteiras seria uma tarefa difícil na rotina diária, de acordo com Dias (2014) e Monteiro (2016).

Em relação aos parâmetros físicos deste estudo, apresentamos no Quadro 2 informações para auxiliar a compor o contexto sócio-histórico cultural das professoras. Pode-se observar ainda que, como mencionado anteriormente, há diferenças no momento de geração de dados. Porém, a pesquisadora e docente ${ }^{11}$ do curso de letras participou diretamente da geração de dados em ambos os casos: em 2014, ao realizar a entrevista com Stephany (DIAS; BROSSI, 2015) e, em 2015, com Iza, ao produzir e aplicar os questionários e conduzir a sessão reflexiva mediada por desenho, que ocorreu como atividade realizada no curso de extensão, do qual Iza participava, no qual a primeira autora/pesquisadora atuava.

11 Primeira autora deste artigo. 
Quadro 2 - Contexto físico de produção

\begin{tabular}{|l|l|}
\hline \multicolumn{2}{|c|}{ PARÂMETROS FÍSICOS } \\
\hline Lugar físico da produção & UEG câmpus Inhumas \\
\hline Momento da produção & $\begin{array}{l}\text { Stephany - 2014 } \\
\text { Iza - 2015 }\end{array}$ \\
\hline Emissores & $\begin{array}{l}2 \text { professoras de inglês atuantes nos anos } \\
\text { iniciais da rede pública }\end{array}$ \\
\hline O receptor & $\begin{array}{l}\text { Pesquisadora e docente formadora do curso de } \\
\text { letras da UEG Inhumas. }\end{array}$ \\
\hline $\begin{array}{l}\text { Finalidade da interação estabelecida entre } \\
\text { interlocutor e destinatário }\end{array}$ & $\begin{array}{l}\text { Stephany - Colaboração com a pesquisa. } \\
\text { Iza - participação no curso de extensão: forma- } \\
\text { ção docente: ensino de inglês para crianças }\end{array}$ \\
\hline
\end{tabular}

Fonte: Elaboração própria.

A seguir, destacamos os parâmetros sociointeracionais no sentido de analisar as diferenças contextuais, dentre as quais enfatizamos o lugar social de Stephany e Iza: enquanto a primeira foi observada e entrevistada como a professora de LIC, a última ocupava o lugar de aluna no referido curso de extensão. Apontamos ainda a diferença entre a finalidade de interação estabelecida pelos parâmetros físicos e os sociointeracionais ou subjetivos. Enquanto Stephany participou do estudo em uma atitude de colaboração com a pesquisa de Dias (2014), a participação de Iza ocorreu em interação estabelecida por meio do envolvimento e participação no curso de extensão. No entanto, no Quadro 3, notamos que a interação ocorreu no intuito de promover o debate quanto à (não) formação de professores de LIC no curso de letras.

12 O curso de extensão Formação docente: ensino de inglês para crianças foi a primeira ação de extensão da UEG Inhumas voltada, especificamente, para discutir acerca do ensino de LIC e da formação de professores para atuar neste contexto. O curso ocorreu em 2014, 2015 e 2016. 
Quadro 3 - Levantamento do contexto sociossubjetivo.

\begin{tabular}{|c|c|}
\hline \multicolumn{2}{|c|}{ PARÂMETROS SOCIOINTERACIONAIS OU SOCIOSSUBJETIVOS } \\
\hline Lugar social & $\begin{array}{l}\text { Stephany - Projeto de pesquisa: “O planeja- } \\
\text { mento de curso, as crenças e ações de pro- } \\
\text { fessores de Língua Inglesa nos anos iniciais: } \\
\text { educação ou sofrimento?” } 2012 \text {. } \\
\text { Iza - Projeto de extensão - Formação docente: } \\
\text { ensino de inglês para crianças. } 2015\end{array}$ \\
\hline O papel social do enunciador & $\begin{array}{l}\text { Stephany - Professora } \\
\text { Iza - professora e aluna no curso de extensão }\end{array}$ \\
\hline Papel social do receptor & Pesquisadora e professora formadora \\
\hline $\begin{array}{l}\text { Finalidade da interação estabelecida entre } \\
\text { interlocutor e destinatário }\end{array}$ & $\begin{array}{l}\text { Promover o debate a respeito da importância } \\
\text { em adequar a formação de professores no } \\
\text { curso de letras, e outros cenários com ensino } \\
\text { de inglês nos anos iniciais. }\end{array}$ \\
\hline
\end{tabular}

Fonte: Elaboração própria.

Os dados foram gerados e tratados conforme os objetivos das pesquisas de cada graduanda. No estudo de Dias (2014), o objetivo do trabalho de conclusão de curso da graduanda foi mostrar como se configurava o ensino de LI nos anos iniciais em uma escola pública municipal de uma cidade do interior de Goiás. Já o trabalho de conclusão de curso de Monteiro (2016) objetivou analisar e comprovar de que forma o curso de extensão contribuiu para o aprendizado e reflexão a respeito da vida docente de um acadêmico de letras - português, inglês no ensino fundamental I, e como este pode prepará-los para o cenário real. Para o presente estudo, recuperamos as transcrições e as categorizamos com vistas a tecer um diálogo entre as vozes das professoras de LIC dos dois estudos, concernente ao ensino como trabalho e sobre a própria formação inicial, os quais apresentamos em seguida.

\title{
Diálogos e desdobramentos sobre o trabalho das professoras
}

\begin{abstract}
"Me sinto triste, às vezes, por não saber o que fazer, como ajudar. Me sinto perdida e, muitas vezes, questiono até a utilidade da LI para algumas crianças. Mas a esperança é o que me mantém firme e não me deixa desistir. Então, me agarro à ela e, dentro de minhas possibilidades, tento fazer o melhor, o que julgo ser o melhor.” Stephany
\end{abstract}

Iniciamos nossas análises buscando dialogar com as falas das professoras, e à luz dos autores que nos fundamentam, apresentando o trecho transcrito da entrevista de Stephany logo após a introdução. A professora se caracteriza por implicar-se em todas 
as suas falas, em um discurso interativo, usando o dêitico de pessoa (eu) e claramente se responsabilizando por suas ações. Optamos por iniciar as nossas discussões com a primeira pergunta de pesquisa, a saber: o que dizem as participantes em referência à sua formação inicial? Ambas corroboram Tutida (2016), ao evidenciarem que não foram preparadas para atuar no ensino de LIC nos anos iniciais do EFI. Iza, ao responder ao questionamento acerca de seu preparo durante a graduação para atuar no ensino de LIC, responde-nos:

\section{Excerto 1:}

Iza - Não. Ao término do curso de Letras, eu estava (e me senti) habilitada somente para o Ensino Fundamental II e Médio. Não tinha noção de como era trabalhar com alunos do $1^{\mathrm{o}}$ ao $5^{\mathrm{o}}$ ano, principalmente a LI. (Q13).

Da mesma forma, Stéphany, quando indagada se diante da sua realidade, ela considera que para o professor de inglês nos anos iniciais, faz mais falta saber a língua inglesa ou faz mais falta ser pedagogo, pondera:

\section{Excerto 2:}

Stephany - Só que eu acho também que não é falta de ser pedagogo, porque eu acho que o professor de inglês não tem que ser pedagogo como o pedagogo é. Eu acho a gente tem que saber lidar com vários tipos de público, e infelizmente na Letras, nós não somos preparados pra lidar com crianças. Na verdade eu acho que deve ter uma mudança aqui na Letras, no curso de Letras [...] trazer um pouco da pedagogia pra cá também [...] infelizmente pelo menos quando eu estudava aqui era o que eu percebia, que estavam me ensinando pra dar aula numa faculdade... porque quando eu fui pro ensino fundamental e pro ensino médio, eu assustei quando eu vi aquilo ali. Ninguém me falava que eu tinha que enfrentar aquilo ali. Então o que eu vejo os professores fazendo... o que eu via era eles... talvez tentando me ensinar a dar aula pra universidade. $\left(\mathrm{E}^{14}\right)$

Stephany tece reflexões acerca do despreparo para o trabalho docente de LIC e aponta outras questões concernentes à formação que recebeu em sua graduação na instituição onde nos encontrávamos. É possível inferir que a participante - situa-se inclusive naquele espaço (aqui, cá, ali) -: evidenciando a distância entre a teoria e a prática, além de possivelmente a ausência de capacidade de relacionar os saberes ensinados no curso de letras e os saberes necessários para exercer sua atividade de ensinar LI para crianças em salas de aula características de escolas públicas. Ao sugerir a aproximação entre o curso de pedagogia e o de letras, Stephany parece evidenciar que

\footnotetext{
13 Q1 - questionário inicial.

14 E- Entrevista.
} 
há um déficit de fundamentos e princípios que auxiliam o/a professor/a a desenvolver seu agir docente, nas esferas de atuação para as quais estava sendo preparada. Corroborando Pessoa e Borelli (2011), nos esforços de formar professores/as orientados por uma "prática reflexiva crítica e criativa, não simplesmente reprodutora", Stephany acrescenta ainda em resposta ao mesmo questionamento:

\section{Excerto 3:}

Stephany - Acho que tem que ter mais essa comunicação universidade/escola, é... professor universitário/professor da escola pública. Tem que ter mais diálogo. (E)

\section{Excerto 4:}

Stephany - Acho que tem que haver esse compartilhamento mesmo, de conhecimento, de experiência, sabe? (E)

Consideramos que, ao usar as modalizações deônticas (BRONCKART, 1999-2003) (tem que), Stephany reforça um discurso coletivo e social, advindo da academia, dos cursos de formação e, possivelmente, de outros colegas de trabalho sobre a necessidade de comunicação entre a escola e a universidade. A professora demonstra aprovação mediante a iniciativa de pesquisarmos o contexto do ensino de LIC com o uso de 'essa' e 'esse', referindo à comunicação e compartilhamento que buscávamos por meio da pesquisa. Reconhecemos que, a contar deste excerto (e de toda a investigação realizada com Stephany), foi concebido o curso de extensão de formação docente para o ensino de LIC que teve sua edição inaugural em 2015, logo após a apresentação dos resultados do estudo original (DIAS, 2014).

Nesse sentido, quando perguntamos: ao ter contato mais próximo, através do estágio, ou ao concluir o curso, suas expectativas em relação à formação acadêmica foram correspondidas? Iza nos diz:

\section{Excerto 5:}

Iza - Ainda não me imaginava como professora. Meu interesse era me aprofundar nos estudos sobre a língua inglesa. Passei a perceber que a docência exige um papel duplo: conhecimento da disciplina e mobilidade didática. Pude ver que só conhecer a língua não era suficiente para lidar com um público cada vez mais conectado no mundo globalizado. Por conta disso e pelo pouco aparato da prática, tinha insegurança em lidar com sala de aula. Acreditava que seria incapaz de ministrar aulas de língua inglesa com sucesso ou que outro aluno pudesse se envolver no aprendizado. Principalmente por conta de toda essa cultura que estamos arraigados de que não se aprende inglês na escola. (Q2)

Iza evidencia o caráter de incompletude da formação docente ao perceber que conhecer a língua a ser ensinada não é o suficiente, reforçando assim a importância e 
urgência de que os professores de LIC tenham uma formação específica, relacionando teoria e prática, e fortalecendo a confiança do professor de LIC. Postulamos, com base nas semiotizações de Iza, e ancoradas em Santos e Benedetti (2009), que a professora de LIC vai sendo construída, fundamentada em suas experiências, em uma formação continuada. Iza deixa transparecer que considera necessário conhecer o público-alvo e questionar a crença de que não se aprende inglês na escola pública. A professora enfatiza também que considera relevante a busca por formação continuada durante $o$ exercício da docência.

\section{Excerto 6:}

Iza - Formação e adaptação. Conhecer a língua e as teorias didático-pedagógicas devem se aliar a uma individualidade profissional. Cada situação exige uma prática e não existe um manual com as melhores instruções, mas, sim, uma avaliação crítica contínua para o melhor desempenho nas mais diversas situações. (Q2).

\section{Excerto 7:}

Iza - Eu não estou no desenho, porque eu acredito que o nosso lugar antes de ir pra sala de aula é aqui né, buscando a formação, fazendo a pesquisa, buscando cultura. [...] $\left(\mathrm{SR}^{15}\right)$

Além de enfatizar a importância da formação continuada do professor de LIC, Iza ainda menciona que não há "um manual”, porém há críticas contínuas, apontando a dificuldade em não ter orientações acerca do agir docente, de seu trabalho de ensinar. Entretanto, pode-se notar que Iza revela a crença de que a interação na língua-alvo pode ser desenvolvida no contato com o falante nativo de inglês, evidenciando o discurso social, coletivo de valorização do falante nativo em detrimento do conhecimento local.

\section{Excerto 8:}

Iza - Porque nós temos um grave problema, né, nós vamos pra sala de aula trabalhar o inglês sem saber o mínimo da cultura inglesa, o mínimo da cultura americana, o mínimo sequer de sentar e ter a oportunidade que nós vamos ter no próximo sábado, trabalhar com o professor Lennon que é dos EUA. (SR)

O discurso coletivo enfatizado pelo uso do dêitico 'nós' evidencia que aparentemente há um discurso (implicado) de poder socialmente construído e naturalizado, que atribui maior prestígio à cultura americana, em detrimento de outros falantes da LI, e especialmente desconsiderando toda a trajetória de formação do curso de graduação, além dos conhecimentos (co)construídos em interações com professores formadores falantes de inglês como língua estrangeira. Pode-se inferir ainda que durante sua formação inicial, a professora não teve experiências e reflexões que problematizassem

15 SR - Sessão reflexiva mediada por desenho. 
a competência linguística e profissional entre professores de inglês nativos e falantes de inglês como língua estrangeira. Ademais, do nosso ponto de vista, essa fala denota a visão de que língua e cultura são dissociadas.

Outros tópicos recorrentes nas semiotizações das professoras, o qual analisamos a seguir, são as condições físicas e contextuais tidas como essenciais para o ensino de LIC.

\section{Excerto 9:}

Iza - Então é... pra mim uma sala de aula de inglês para crianças ela tem que ser no mínimo colorida, o ideal para mim seria uma sala de aula temática. O que seria uma sala de aula temática? Uma sala de línguas, como tantos PPPs falam aí e hoje nenhuma escola, pelo menos de 1a fase, tem uma sala de línguas, tem um laboratório; infelizmente né? Por que se você vai trabalhar uma língua a gente tem toda uma carga por trás dela né, então o mínimo que você tem que ter é um computador, um projetor né, já que vai estudar a língua a gente precisa de imagens, precisa de som, você precisa de cor né, principalmente se tratando de criança né. Aí eu traduzi um pouquinho como seria a minha sala ideal, seria uma English Classroom, exclusivamente para o inglês. Eh... ai eu coloquei projetor, cor, música, dicionário, tecnologia que é o que eu mais sofro hoje em dia né, porque o quê que adianta as crianças brincarem com tablets em casa, computadores e celulares né, com smartphones, chega lá na escola você tem xerox preto e branco partida ao meio né. Eh... textbook que eu coloquei que é um livro didático que eu ainda não achei nenhum que sane a minha sede de ensinar, eh... lápis de cores, as canetinhas, música, os pôsteres [...] (SR)

Iza menciona a sala de aula temática, os recursos mediadores da ação do professor, especificamente para o trabalho docente com crianças, apontando ainda a característica do déficit de ferramentas tecnológicas que poderiam promover maior interesse e motivação entre as crianças.

Por outro lado, observa-se que a visão posta por Stephany vai ao encontro do exposto por Bronckart (1999-2003) no sentido de que para falar sobre o trabalho realizado a professora de LIC assume uma voz social (a gente) ao mencionar que questões pessoais interferem não somente no trabalho docente, mas também na aprendizagem da criança, ao mesmo tempo em que se coloca revelando seu agir de professora pautada na perspectiva crítica, uma vez que compreende a influência de problemas vividos em casa, na aprendizagem da criança.

\section{Excerto 10:}

Stephany - É... E em casa, quando o seu trabalho não está bem, tem reflexo em casa e vice-versa. Então a gente tem que considerar tudo isso, não dá pra isolar. O aluno, às vezes, é um bom aluno, mas tem dias que ele não está bem. Então às vezes é alguma coisa acontecendo na casa dele. Eu não posso obrigar ele a dar a resposta que eu quero, sabe. É complicado isso. (E) 
Stephany revela a voz social ao usar 'a gente' e se implicar nesse grupo que 'tem que considerar tudo isso', evidenciando o perfil de uma professora compreensiva e paciente mediante as situações 'conturbadas' vivenciadas pelas crianças da escola pública, que podem prejudicar o desenvolvimento delas.

\section{Excerto 11:}

Stephany - [...] Muitos não têm apoio familiar pra estudar, e eu não sei como que isso funciona. Mas a vida da criança, de qualquer criança hoje em dia é muito conturbada. Elas estão vivendo como adultos, né? Infelizmente. (E)

\section{Excerto 12:}

Stephany - [...] Muitas crianças, hoje em dia, vivem problemas que os adultos vivem. Por exemplo, tenho uma aluna que tem que cuidar da irmã mais nova e de si mesma porque a mãe tem que trabalhar. Uma outra, não tem pai e sua mãe é usuária [...] (E)

Os excertos de Stephany demonstram, a nosso ver, traços de uma professora que tem a intenção de entender a realidade das famílias e das crianças, além de reconhecer a necessidade de aulas contextualizadas e significativas para manter o interesse das crianças e sua motivação. Acreditamos que essas características fazem parte do perfil de professores de LIC, além do já mencionado por Santos (2009).

\section{Excerto 13:}

Stephany - [...] estão interessados em aprender aquilo que... estimula eles, aquilo que interessa, que desperta o interesse deles. Eu acho que eles querem aprender o que faz parte da realidade do mundo deles. Acho que é isso ... Quando é uma coisa muito distante eles dizem: Ixi. Às vezes eu até acho legal, mas eu percebo o desinteresse. Agora se é uma coisa que eles vivem, que eles veem, que eles ouvem, que eles sabem que podem vir a usar ou que eles percebem que podem usar pelo menos ali comigo, eles se interessam. Mas o que eu percebo também, é que... para que eu mantenha esse interesse, eu tenho que sempre que estar... [risos]. Sabe? Sempre feliz, sempre estimulando. E é muito cansativo. (E)

\section{Excerto 14:}

Stephany - Então eu tenho que mostrar interesse também pra que eles tenham a resposta que eu quero né? Eu tenho que estar bem também [...]. (E)

Stephany evidencia a pressão sofrida por professores em geral e o desgaste físico e emocional peculiares do trabalho docente com crianças, que naturalmente exigem mais envolvimento do professor em razão das necessidades de desenvolvimento sóciopsicoafetivas da faixa etária (VYGOTSKY, 1998; MELLO, S., 2007), e a intenção 
da professora em manter o interesse das crianças. Stephany se expressa usando as modalizações deônticas (tenho que) inclusive se implicando no discurso por meio de dêiticos de pessoa (eu), que demonstram o perfil de uma professora consciente de seu papel. É possível afirmar ainda que, para Stephany, o equilíbrio emocional e a capacidade de manter a criança interessada e motivada, são características essenciais para exercer o trabalho docente, constituindo o agir de professores de LIC. No que tange ao metier desse profissional, podemos inferir que a participante defende que conhecer o desenvolvimento de diversos aspectos significativos da criança, saber adequar os conteúdos às suas peculiaridades e gostar de realizar tarefas que envolvem a ludicidade são características do agir docente para o ensino de LIC.

Corroboramos com Stephany - excertos 15 e 16 - ao afirmar que para que os objetivos de tal ensino sejam alcançados, é essencial que o/a professor/a de LIC tenha uma formação que inclua o estudo das características e capacidades das crianças (6 - 12 anos), por meio de um currículo interdisciplinar, que envolva a psicologia, a pedagogia, a sociologia, além dos estudos da linguística aplicada e letras - assumindo um cunho transdisciplinar, na construção de uma ciência do humano (BRONCKART, 1999-2003).

\section{Excerto 15:}

Stephany - É... eu acho que no início, principalmente no iniciozinho tem que ser mais lúdico né? Eu acho que o importante é fazer eles gostarem, porque na verdade eu ainda não consegui fazer os do iniciozinho se comunicarem... sabe [...] (E)

\section{Excerto 16:}

Stephany - [o que deve ser ensinado para crianças] Na minha opinião, brincadeiras, histórias, músicas, atividade simples...Acho o conteúdo relativo. Qualquer conteúdo pode ser ensinado, dependendo da forma que se ensina. (Q1)

A análise do discurso dessa participante nos dá pistas de que compreender a relevância da ludicidade constitui-se como uma regra do ofício (AMIGUES, 2004) de ensinar LIC, assim como ter a capacidade de adequar "qualquer conteúdo" às necessidades essenciais da criança. Pode-se inferir também que ao se instrumentalizar por meio da apropriação de artefatos mediadores (ROSOLEM, 2015) característicos do ensino de LIC - brincadeiras, histórias, músicas - Stephany demonstra a internalização que propicia a transformação do ambiente físico e/ou social, desenvolvendo capacidades para agir sobre o mundo e sobre o outro (LOUSADA; MACHADO, 2010), tornando os artefatos instrumentos psicológicos (VYGOTSKY, 1998) do agir docente. 


\section{Considerações finais}

Este artigo objetivou conhecer a atividade do/a professor/a de língua inglesa para crianças (LIC) e as dimensões do agir docente com base nos dizeres das professoras investigadas. Para atingir tal objetivo, procuramos responder a dois questionamentos. No que se refere ao primeiro deles, "o que dizem as professoras concernente à sua formação inicial?", podemos afirmar que Stephany e Iza confirmam os resultados de Tutida (2016), de que os/as professores/as graduados/as em letras não se sentem preparados/as para atuar no EFI, com o ensino de LIC.

A análise das semiotizações das professoras evidencia que ambas reforçam a falta de formação propiciada por fundamentos e princípios para desenvolver seu agir. As professoras indicam que deveria haver interação mais próxima entre a teoria e a prática, dado que está diretamente relacionado ao próximo resultado, que é a necessidade de formação pedagógica e didática, além de uma formação crítica e para a justiça social, empatia pela criança, sendo capaz de se colocar no lugar do outro para o ensino de LIC. Elas reforçam ainda a falta de ferramentas para a atividade docente.

Stephany, por sua vez, demonstra maior identificação com a atividade de ensinar LIC, implicando-se em seu discurso, além de evidenciar a presença dos objetos constitutivos do agir docente (AMIGUES, 2004) e a internalização dos artefatos mediadores desse trabalho complexo de ensinar inglês no EFI.

Em relação à segunda questão "De que forma a análise das semiotizações das duas professoras podem contribuir para a formação de professores/as de LIC?” as reflexões tecidas neste estudo levam-nos a crer que é necessária uma adequação no currículo do curso de letras, com foco na formação do/a professor/a, alicerçado nas dimensões, dos objetos, saberes necessários e análise do agir docente em ambiente real de ensino de LIC nos anos iniciais do EFI. As especificidades do desenvolvimento das crianças (de 6 a 12 anos), assim como o uso dos artefatos mediadores e a metodologia, não são contemplados no decorrer da formação de professores/as, causando frustração nestes/ as a contar do momento que estão habilitados para o início da atividade de ensinar.

Nossas reflexões quanto ao trabalho do/a professor/a de LIC e da constituição do agir desses/as profissionais do ensino nos permitiram tecer algumas reflexões e propor encaminhamentos com vistas a estabelecer sentidos para a formação específica de professores/as de LIC. Concordamos com as professoras participantes, que há aspectos essenciais do agir docente de LIC, que envolvem toda a dimensão do humano de um/a professor/a, tanto no âmbito de características pessoais, quanto em atitudes, capacidades e habilidades a serem desenvolvidas:

1 - conhecer o desenvolvimento global da criança;

2 - saber adequar os conteúdos às características infantis;

3 - gostar de fazer atividades lúdicas;

4 - apropriar-se de brincadeiras, histórias infantis, músicas e outros instrumentos para agir sobre e com a criança. 
Incentivamos a problematização do agir docente tanto na formação inicial quanto na continuada, na graduação, em ações de extensão e na pós-graduação, a fim de atender a uma demanda real, desse contexto em expansão.

Concluímos que as professoras investigadas enfatizam algumas características necessárias ao perfil de professores/as de LIC, dentre elas a capacidade de se colocar no lugar da criança, de adequação dos conteúdos à faixa etária e contexto local, além de internalizar os instrumentos mediadores e ser emocionalmente equilibrado/a para favorecer a aprendizagem, e manter o interesse das crianças.

Algumas crenças foram também mencionadas, tais como a professora de LIC precisa estar sempre motivada e deve tentar se aproximar da cultura americana e ou inglesa, o que evidencia a supervalorização da cultura americana, e as complexidades do imperialismo linguístico ainda latente e pouco problematizado na graduação. Consideramos relevante apontar que os conhecimentos apropriados no decorrer de um processo de formação continuada, aliados ao desenvolvimento de habilidades, capacidades, gestos característicos do agir docente de LIC, em uma formação reflexiva e crítica, questionadora e voltada para a transformação da realidade onde estão inseridas, podem contribuir para a ressignificação das crenças e concepções reveladas nos discursos das participantes.

Acreditamos que as discussões e diálogos aqui travados, a contar das semiotizações de professoras de LIC, possam contribuir para o fortalecimento das identidades profissionais de professores de LIC que atuam em todas as esferas, desde a educação infantil ao ensino fundamental II, visto que as duas participantes parecem construir essa identidade e seu agir na própria prática.

Apesar da constatação de que a lacuna na formação de professores de LIC interfere sobremaneira na constituição do agir docente desses professores que atuam nesta esfera, defendemos as iniciativas que já ocorrem, de forma difusa, porém marcante. Muitas ações têm sido criadas, desenvolvidas e implantadas a começar de esforços e interesses individuais e coletivos, de grupos de formadores nas Instituições de Ensino Superior aqui representadas UEG e UEL). Ações que vão desde a inserção de disciplinas optativas, projetos de extensão de ensino de LIC, oferta de estágio supervisionado, cursos de formação docente, eventos, palestras, e inclusive curso de pós-graduação lato sensu em ensino de LIC, para preencher, pelo menos parcialmente, essa lacuna da formação inicial na graduação em letras.

Esperamos que as discussões propostas neste estudo colaborem com pesquisas futuras as quais também tratam do ensino de LIC, materializando características do agir desses/as professores/as, e que munidos deste conhecimento os/as professores/as formadores possam construir um currículo para o curso de letras que contemple reflexões e ações formativas que auxiliem o/a futuro/a professor/a de LIC a compreender melhor a atividade docente e as dimensões constitutivas desse agir. 
BROSSI, G.; TONELLI, J. The construction of the teacher's action by English teachers for children: a view to teaching as labor. Alfa, São Paulo, v.65, 2021.

- ABSTRACT: This article aims at recognizing the activity of teaching English as a Foreign Language to children and the dimensions of the teacher action based on the theoretical and methodological principles of the Sociodiscursive interactionism (BRONCKART, 1999-2003; 2007; 2008). The data were resumed from two case studies from 2013/2014 and 2015/2016. The theoretical input examines the existing gap in the Humanities curriculum education regarding teaching English to children in Brazil (ROCHA; BASSO, 2007, 2012; ROCHA; TONELLI; SILVA, 2010; TONELLI; FERREIRO; BELO-CORDEIRO, 2017; SANTOS; BENEDETTI, 2009), on behalf of children's particularities (VYGOTSKY, 1998), and education for a critical citizenship (ROCHA; BASSO, 2007; PESSOA; BORELLI, 2011). Teaching as labor and how the teacher's action is shaped (FAĬTA, 2004; AMIGUES, 2004; MACHADO, 2004) anchor the analyses of the teachers' reflections. Data were generated through interviews and a reflexive session based upon a drawing (TONELLI, 2016). Data analyses reinforced the relevance of teacher education targeted at the specific traces of the English to children teaching education activity, composed of every dimension of the human being. It also revealed teachers' beliefs about teaching EFLC in public schools as well as traces of linguistic imperialism influence.

- KEYWORDS: teaching activity; ergonomics; critical teacher education; English for children; sociodiscursive interactionism.

\section{REFERÊNCIAS}

AMIGUES, R. Trabalho do professor e trabalho de ensino. In: MACHADO, A. R. (org.). O ensino como trabalho: uma abordagem discursiva. Londrina: Eduel, 2004. p.35-53.

ANDRADE, M. E. S. F.; CONCEIÇÃO, M. P. Letramento em língua estrangeira no Ensino Fundamental: ampliando o exercício de cidadania das crianças brasileiras. In: TONELLI, J. R. A.; PÁDUA, L. de S.; OLIVEIRA, T. R. R. Ensino e formação de professores de línguas estrangeiras para crianças no Brasil. Curitiba: Appris, 2017. p.121- 149 .

BAKHTIN, M. M.; VOLOCHÍNOV, V. N. Marxismo e filosofia da linguagem: problemas fundamentais do método sociológico na ciência da linguagem. Tradução Michel Laud e Yara F. Vieira. 8.ed. São Paulo: Hucitec, 1997.

CLOT, Y. A função psicológica do trabalho. Trad. Adail Sobral. 2.ed. Petrópolis: Vozes, 2007.

BRASIL. Ministério da Educação. Documento Final da Conferência Nacional de Educação (Conae). Brasília: MEC, 2014. Disponível em: http://fne.mec.gov.br/images/ doc/DocumentoFina240415.pdf. Acesso em: 13 jan. 2015. 
BRASIL. Ministério da Educação. Parecer CNE/CES 1.363. Retifica o Parecer CNE/ CES n. ${ }^{\circ}$ 492, de 3 de abril de 2001, que aprova as Diretrizes Curriculares Nacionais dos cursos de Arquivologia, Biblioteconomia, Ciências Sociais - Antropologia, Ciência Política e Sociologia, Comunicação Social, Filosofia, Geografia, História, Letras, Museologia e Serviço Social. Diário Oficial da União: seção 1, Brasília, DF, p.60, 29 jan. 2002.

BRASIL. Ministério da Educação. Parecer CNE/CES 492/2001. Diretrizes Curriculares Nacionais para os Cursos de Filosofia, História, Geografia, Serviço Social, Comunicação Social, Ciências Sociais, Letras, Biblioteconomia, Arquivologia e Museologia. Diário Oficial da União: seção 1, Brasília, DF, p.50, 09 jul. 2001.

BRONCKART, J. Atividade de linguagem, texto e discursos: por um interacionismo sociodiscursivo. Tradução Anna Raquel Machado, Péricles Cunha. São Paulo: Educ, 1999-2003.

BRONCKART, J. A atividade de linguagem frente à língua: homenagem a Ferdinand Saussure. In: GUIMARÃES, A. M. de M.; MACHADO, A. R.; COUTINHO, A. (org.). O interacionismo sociodiscursivo: questões epistemológicas e metodológicas. Campinas: Mercado de Letras, 2007. p.19-43.

BRONCKART, J. O agir nos discursos: das concepções teóricas às concepções dos trabalhadores. Campinas: Mercado de Letras, 2008.

BROSSI, G. C.; TONELLI, J. R. A.FURIO, M. O agir de professores de inglês para crianças em formação inicial: conhecendo dois contextos. In: SILVA, A. P. de P.; SANTOS, L. I. S.; PHILIPSEN, N. I. (org.). Formação, docência e práticas pedagógicas em linguagens: diferentes contextos em diálogo. Campinas: Pontes, 2018. p.231-266.

BUOSE, V. L. P. de O.; SANTOS, L. I. S. Oficina de língua inglesa para criança: uma sequência didática com gênero textual em ação. In: TONELLI, J. R. A.; PÁDUA, L. de S.; OLIVEIRA, T. R. R. Ensino e formação de professores de línguas estrangeiras para crianças no Brasil. Curitiba: Appris, 2017. p.9-120.

CELANI, M. A. A. Um desafio na Linguística Aplicada contemporânea: a construção de saberes locais. DELTA, São Paulo, v.32, n.2, p.543-555, 2016. Disponível em: http:// www.scielo.br/scielo.php?script=sci_arttext\&pid=S0102-44502016000200543\&lng= pt\&nrm=iso. Acesso em: 20 abr. 2019.

CHAGURI, J. de P.; TONELLI, J. R. A. Existe uma política de ensino-aprendizagem de língua estrangeira para crianças? In: TONELLI, J. R. A.; CHAGURI, J.de P. Ensino de língua estrangeira para crianças: o ensino e a formação em foco. Curitiba: Appris, 2012. p.37-57. 
COLOMBO, C. S.; CONSOLO, D. A. Ensino de inglês como língua estrangeira para crianças: a qualidade do insumo oral. In: TONELLI, J. R. A.; PÁDUA, L. de S.; OLIVEIRA, T. R. R. Ensino e formação de professores de línguas estrangeiras para crianças no Brasil. Curitiba: Appris, 2017. p.207-224.

DIAS, J. K. O. Compondo a profissão: reflexões e ações que norteiam a prática de uma professora de língua inglesa para crianças. 55f. Monografia (Graduação em Letras Português/Inglês) - Universidade Estadual de Goiás, Inhumas, 2014.

DIAS, J. K. O.; BROSSI, G. C. Reflexões e inquietações acerca do ensino de língua inglesa nos anos iniciais. Pesquisas em Discurso Pedagógico, Rio de Janeiro, v.1, p.1-26, 2015. Disponível em: https://www.maxwell.vrac.puc-rio.br/24802/24802.PDF $\mathrm{XXvmi}=$. Acesso em: 20 jul. 2018.

DUBOC, A. P. Atitude curricular: letramentos críticos nas brechas da formação de professores de inglês. 246f. Tese (Doutorado em Estudos Linguísticos e Literários em Inglês) - Faculdade de Filosofia, Letras e Ciências Humanas, Universidade de São Paulo, São Paulo, 2012.

EGIDO, A. A. Students' assumption, prejudice, and discrimination in an English language class. Curitiba: Appris, 2018.

ENEVER, J. ELLIE: Early Language Learning in Europe. London: British Council, 2011.

ESPINASSY, L. Analyse de l'activité des professours d'arts plastiques au collège. In: AMIGUES, R.; FAĬTA, D.; KHERROUBI, M. (éd.). Metier einsegnant, organisation du travail et analyse de l'activité. Skohlé, 2003.

FACCI, M. G. D. A periodização do desenvolvimento psicológico individual na perspectiva de Leontiev, Elkonin e Vigotsky. Cadernos CEDES, Campinas, v.24, n.62, p.64-81, 2004. Disponível em: https:/www.scielo.br/j/ccedes/a/3Nc5fBqVp6 SXzD396YVbMgQ/abstract/?lang=pt. Acesso em: 20 jul. 2018.

FAĬTA, D. Gêneros de discurso, gêneros de atividade, análise da atividade do professor. In: MACHADO, A. R. (org.). O ensino como trabalho: uma abordagem discursiva. Londrina: EDUEL, 2004. p.55-80.

JOHNSON, K. E. The sociocultural turn and its challenges for second language teacher education. TESOL Quarterly, Washington, n.40, v.1, p.235-257, 2006.

JORGE, M. L. dos S. Preconceito em relação ao ensino de língua estrangeira na rede pública de ensino. In: LIMA, D. C. de. (org.). Ensino e aprendizagem de língua inglesa: conversas com especialistas. Campinas: Parábola, 2009. p.161-168.

LEMES, F. M. M. Formação crítica docente e seu reflexo no ensino crítico de inglês para crianças: experiências transformadoras. In: TONELLI, J. R. A.; PÁDUA, L. de 
S.; OLIVEIRA, T. R. R. Ensino e formação de professores de línguas estrangeiras para crianças no Brasil. Curitiba: Appris, 2017. p.151-175.

LOUSADA, E.; MACHADO, A. R. A apropriação de gêneros textuais pelo professor: em direção ao desenvolvimento pessoal e à evolução do "métier". Linguagem em (Dis)curso, Palhoça, v.10, n.3, p.6019, 2010.

MACHADO, A. R. Por uma concepção ampliada do trabalho do professor. In: GUimarÃES, A. M. de M.; MACHADO, A. R.; COUTINHO, A. (org.). O interacionismo sociodiscursivo: questões epistemológicas e metodológicas. Campinas: Mercado de Letras, 2007. p.77-97.

MACHADO, A. R. (org.). O ensino como trabalho: uma abordagem discursiva. Londrina: Eduel, 2004.

MACHADO, A. R.; ABREU-TARDELLI, L. S.; CRISTOVAO, V. L. L. Linguagem e educação: o trabalho do professor em uma nova perspectiva. Campinas: Mercado de Letras, 2009.

MELLO, M. G. B. Política pública para implementação do ensino de língua inglesa nos anos iniciais do Ensino Fundamental: o exemplo de Rolândia, PR. In: TONELLI, J. R. A.; PÁDUA, L. de S.; OLIVEIRA, T. R. R. Ensino e formação de professores de línguas estrangeiras para crianças no Brasil. Curitiba: Appris, 2017. cap. 9.

MELLO, S. A. As práticas educativas e as conquistas de desenvolvimento das crianças pequenas. In: RODRIGUES, E.; ROSIN, S. M. (org.). Infância e práticas educativas. Maringá: Eduem, 2007. p.11-22.

MOITA LOPES, L. P. da. Uma linguística aplicada mestiça e ideológica: interrogando o campo como linguista aplicado. In: MOITA LOPES, L. P. da. Por uma linguística aplicada Indisciplinar. São Paulo: Parábola Editorial, 2006. p.13-42.

MONTEIRO, K. K. da S. O ensino de língua inglesa para crianças: reflexões a respeito do cenário real de formação de professores em Inhumas. Monografia (Graduação em Letras Português/Inglês) - Universidade Estadual de Goiás, Inhumas, 2016.

PESSOA, R. R.; BORELLI, J. D. V. P. Reflexão e critica na formação de professores de língua estrangeira. Goiânia: Ed. da UFG, 2011.

RABARDEL, P. Les hommes et les technologies. Paris: Armand Colin, 1995.

ROCHA, C. H.; BASSO, E. A. (org.). Ensinar e aprender língua estrangeira nas diferentes idades: reflexões para professores e formadores. São Carlos: Claraluz, 2007.

ROCHA, C. H.; TONELLI, J. R. A.; SILVA, K. A. (org.). Língua estrangeira para crianças: ensino-aprendizagem e formação docente. Campinas: Pontes, 2010. p.149-184. 
ROSOLEM, L. D. D. da L. A linguagem revelando práticas docentes: das prescrições mediadoras de ações educacionais à ação em sala de aula. 174f. Dissertação (Mestrado em Estudos da Linguagem) - Centro de Letras e Ciências Humanas, Universidade Estadual de Londrina, Londrina, 2015.

SANTOS, L. I. S. Crenças acerca da inclusão de língua inglesa nas séries iniciais: quanto antes melhor? 230f. Dissertação (Mestrado em Estudos Linguísticos) - Instituto de Linguagem, Universidade Federal do Mato Grosso, Cuiabá, 2005.

SANTOS, L. I. S. Língua Inglesa em anos iniciais do Ensino Fundamental: fazer pedagógico e formação docente. 274f. Tese (Doutorado em Estudos Linguísticos) Universidade Estadual Paulista, São José do Rio Preto, 2009.

SANTOS, L. I. S.; BENEDETTI, A. M. Professor de língua estrangeira para crianças: conhecimentos teórico-metodológicos desejados. Trabalhos em Linguística Aplicada, Campinas, v.48, n.2, p.333-351, 2009. Disponível em: http://www.scielo.br/scielo.php? script $=$ sci_arttext\&pid=S0103-18132009000200010\&lng=en\&nrm=iso. Acesso em: 20 abr. 2019.

SAUJAT, F. O trabalho do professor nas pesquisas em educação: um panorama. In: MACHADO, A. R. (org.). O ensino como trabalho: uma abordagem discursiva. Londrina: Eduel, 2004. p.3-34.

SELBACH, H. V.; SARMENTO, S. The crazy car story: um projeto em língua inglesa na educação infantil. In: TONELLI, J. R. A.; PÁDUA, L. de S.; OLIVEIRA, T. R. R. Ensino e formação de professores de línguas estrangeiras para crianças no Brasil. Curitiba: Appris, 2017. cap. 11.

TANACA, J. J. Aprendizagem expansiva em espaços híbridos de formação continuada de professoras de inglês para crianças no Projeto Londrina Global. 257f. Tese (Doutorado em Estudos da Linguagem) - Universidade Estadual de Londrina, Londrina, 2017.

TONELLI, J. R. A. Professores de língua adicional para crianças: atores de espaços vazios? In: REIS, S. (org.). História, políticas e ética na área profissional da linguagem. Londrina: Eduel, 2017. p.67-84.

TONELLI, J. R. A. Histórias infantis no ensino da língua inglesa para crianças. 312f. Dissertação (Mestrado em Estudos da Linguagem) - Universidade Estadual de Londrina, Londrina, 2005.

TONELLI, J. R. A. Contextos (in)explorados no estágio supervisionado nas licenciaturas em letras/inglês: o lugar da observação de aulas nos dizeres de alunos-mestres. Signum: Estudos da Linguagem, Londrina, v.19, n.2, p.35-65, 2016.

TONELLI, J. R. A.; CRISTOVÃO, V. L. L. O papel dos cursos de Letras na formação de professores de inglês para crianças. Calidoscópio, São Leopoldo, v.8, n.1, p.65-76, 2010. 
TONELLI, J. R. A.; FERREIRA, O. H. S.; BELO-CORDEIRO, A. E. Remendo novo em vestido velho: uma reflexão sobre os cursos de letras-inglês. REVELLI: Revista de Educação, Língua e Literatura, Inhumas, v.9, p.124-141, 2017.

TUTIDA, A. F. Ensino de língua inglesa para crianças: questões sobre formação de professores e os saberes da prática. 314f. Dissertação (Mestrado em Estudos da Linguagem) - Universidade Estadual de Londrina, Londrina, 2016.

VIGOTSKI, L. S. A formação social da mente: o desenvolvimento dos processos psicológicos superiores. Tradução José Cipolla Neto, Luís Silveira Menna Barreto, Solange Castro Afeche. 6.ed. São Paulo: Martins Fontes, 1998.

YIN, R. K. Estudo de caso: planejamento e métodos. 2.ed. Porto Alegre: Bookman. 2001. 


\section{APÊNDICE A}

Roteiro de entrevista (DIAS, BROSSI, 2015)

1. Você sabe se a necessidade que o município viu de ter o inglês nos anos iniciais partiu dos professores que pediram? Ou se foi a própria secretaria da educação que teve essa iniciativa?

2. Você diria que consegue alcançar seus objetivos em 01 hora por semana de ensino de inglês nos anos iniciais?

3. Qual é a metodologia que funciona melhor para o ensino de LI nos anos iniciais na sua opinião? E especificamente no $1^{\circ}$ e $2^{\circ}$ anos?

4. Qual a habilidade deve ser mais trabalhada nos anos iniciais para você? E especificamente no $1^{\circ}$ e $2^{\circ}$ anos?

5. Como é feita a seleção de conteúdos para os anos iniciais? O planejamento vem da secretaria da educação? É o mesmo? Esse plano anual é feito por vocês colaborativamente?

6. E então, diante dessa realidade, você entende que para o professor de inglês, nos anos iniciais, faz mais falta saber a língua inglesa ou faz mais falta ser pedagogo?

7. Você considera que alcançou seus objetivos em 2013 nos anos iniciais? E no $1^{\circ}$ ano?

8. Qual é o papel da música na aprendizagem de LI no $1^{\circ}$ ano?

9. Que tipo de conteúdo deve ser priorizado nos anos iniciais?

10. Você tem liberdade para ensinar? O que tolhe a sua liberdade de ensinar como você deseja?

11. Você trabalhou da forma que queria? Justifique.

12. Vocês (professores/as) de Inhumas trabalham em colaboração?

13. Comente:

a. Os/as alunos/as estão interessados em aprender coisas fáceis.

b. O/A aluno/a motivado/a aprende melhor.

c. O contexto da escola dificulta a aprendizagem de LI.

d. Cabe ao/a professor/a despertar o gosto do/a aluno/a pela língua e diminuir as barreiras?

Recebido em 9 de dezembro de 2019

Aprovado em 22 de setembro de 2020 